\title{
IMPLEMENTASI JAMINAN KESEHATAN DAERAH: STUDI KASUS DI KABUPATEN SLEMAN
}

\author{
Sukarno $^{1}$ dan Ani Nurhayati ${ }^{2}$
}

\begin{abstract}
The purpose of this article was to know the implementation of regional health insurance. This research is empirical juridical research. This research was conducted with field research aimed at the implementation of regional health insurance after the enactment of Sleman Regent Regulation No. 60 of 2012. The results of this research indicated that the implementation of regional health insurance after the enactment of Sleman Regent Regulation No. 60 of 2012 follow: Regional Health Insurance Program in Sleman District has a goal to provide quality and affordable services to the community, maximizing health financing for the Sleman Slum community. Each JAMKESDA participant had the right to receive basic health services including outpatient and inpatient services, as well as Advanced Advanced Outpatient Health Care (RJTL), Advanced Inpatient (RITL), delivery and emergency care services. Constraints faced include limited local budgets for regional financing and inadequate health facilities and resources. In addition, other obstacles related to procedural administrative, constraints derived from data collection, constraints that are socio cultural and human resource constraints (HR).
\end{abstract}

Keywords: Implementation, Health Insurance, Regional.

\begin{abstract}
ABSTRAK
Tujuan penulisan ini adalah mengetahui implementasi jaminan kesehatan daerah. Penelitian ini bersifat penelitian yuridis empiris. Penelitian ini dilakukan dengan penelitian lapangan yang ditujukan pada implementasi jaminan kesehatan daerah setelah berlakunya Peraturan Bupati Sleman Nomor 60 Tahun 2012. Hasil penelitian menunjukkan bahwa implementasi jaminan kesehatan daerah setelah berlakunya Peraturan Bupati Sleman Nomor 60 Tahun 2012 adalah sebagai berikut: Program Jaminan Kesehatan Daerah di Daerah Sleman ini memiliki tujuan untuk memberikan pelayanan yang bermutu dan terjangkau kepada masyarakat, memaksimalkan pembiayaan kesehatan bagi masyarakat miskin Daerah Sleman. Setiap peserta Jamkesda mempunyai hak mendapatkan pelayanan kesehatan dasar meliputi pelayanan kesehatan rawat jalan dan rawat inap, serta pelayanan kesehatan rujukan Rawat Jalan Tingkat Lanjutan (RJTL), Rawat Inap Tingkat Lanjutan (RITL), pertolongan persalinan dan pelayanan gawat darurat. Kendala yang dihadapi antara lain keterbatasan anggaran daerah untuk pembiayaan daerah dan fasilitas dan sumber daya kesehatan yang belum memadai. Selain itu kendala lain yang berkaitan dengan prosedural administratif, kendala yang bersumber dari pendataan, kendala yang bersifat sosio kultural serta kendala Sumber Daya Manusia (SDM).
\end{abstract}

Kata kunci: Implementasi, Jaminan Kesehatan dan Daerah.

\footnotetext{
1,2 Fakultas Hukum Universitas Cokroaminoto Yogyakarta. email: sukarno_notppat@yahoo.com
} 


\section{PENDAHULUAN}

Pembangunan adalah proses perubahan yang dilakukan melalui upayaupaya secara sadar dan terencana dengan melakukan perkembangan yang merupakan proses perubahan yang didasarkan pada kebutuhan akan kehidupan yang lebih baik. Dalam hal ini pembangunan mencakup aspek yang multidimensional, dan salah satu aspeknya adalah pembangunan kesehatan yang merupakan kunci sukses yang mendasari pembangunan lainnya, dengan kata lain kesehatan merupakan kebutuhan manusia yang utama dan menjadi prioritas yang mendasar bagi kehidupan.

Tujuan peningkatan upaya kesehatan adalah untuk menyelenggarakan upaya kesehatan yang bermutu, merata, dan terjangkau oleh masyarakat, khususnya masyarakat berpenghasilan rendah dan tidak memiliki jaminan kesehatan. Peningkatan upaya kesehatan ini diselenggarakan melalui pendekatan pelayanan medis di Puskesmas, dan terutama di rumah sakit.

$$
\text { Pemerintah sebagai yang }
$$
bertanggung jawab atas pemeliharaan kesehatan harus pula memenuhi kewajiban dalam upaya meningkatkan kesejahteraan seluruh rakyat dan penyediaan sarana pelayanan kesehatan demi melindungi Hak Asasi Manusia, seperti yang termaktub pada Pasal $28 \mathrm{H}$ (Ayat 1) UUD 1945, “Setiap orang berhak hidup sejahtera lahir dan bathin, bertempat tinggal, dan mendapatkan lingkungan hidup yang baik dan sehat serta berhak memperoleh pelayanan kesehatan”, serta (Ayat 3) UUD 1945, "Setiap orang berhak atas jaminan sosial yang memungkinkan pengembangan dirinya secara utuh sebagai manusia yang bermartabat.

Pelayanan di bidang kesehatan merupakan salah satu bentuk pelayanan yang paling banyak dibutuhkan oleh masyarakat. Tidak mengherankan apabila bidang kesehatan perlu untuk selalu di benahi agar bisa memberikan pelayanan kesehatan yang terbaik untuk masyarakat. Pelayanan kesehatan yang dimaksud tentunya adalah pelayanan yang cepat, tepat, murah dan ramah. Mengingat bahwa sebuah negara akan bisa menjalankan pembangunan dengan baik apabila didukung oleh masyarakat yang sehat secara jasmani dan rohani.

Berangkat dari kesadaran tersebut, beberapa rumah sakit maupun Puskesmas yang ada di Indonesia baik milik pemerintah maupun swasta, selalu berupaya untuk memberikan pelayanan yang terbaik kepada pasien dan keluarganya, baik melalui penyediaan 
peralatan pengobatan, tenaga medis yang berkualitas sampai pada fasilitas pendukung lainnya seperti kantin, ruang tunggu, apotik, dan sebagainya. Dengan demikian masyarakat benar-benar memperoleh pelayanan kesehatan yang tepat dan cepat.

Jamkesda adalah Jaminan Kesehatan Daerah. Program ini berupa bantuan biaya kesehatan (tidak semua gratis) dalam upaya meningkatkan derajat kesehatan setinggi-tingginya sehingga seluruh Warga Sleman dapat menikmati akses terhadap pelayanan kesehatan dan perlindungan dalam memenuhi kebutuhan dasar kesehatan.

Puskesmas adalah sebagai suatu lembaga atau unit kerja atau pelaksana pelayanan yang berada dalam suatu wilayah kecamatan atau pedesaan yang tujuannya adalah untuk meningkatkan pelayanan kesehatan kepada masyarakat yang tinggal di pedesaan yang menjadi pusat kegiatan pembangunan. Dari pengertian tersebut maka Puskesmas adalah merupakan Organisasi Kesehatan fungsional yang langsung berada dalam pengawasan baik administratif maupun teknis dari Dinas Kesehatan Kabupaten.

Bertolak dari pemikiran tersebut di atas, maka penelitian ini mengajukan tiga permasalahan. Pertama, implementasi jaminan kesehatan daerah setelah berlakunya Peraturan Bupati Sleman Nomor 60 Tahun 2012 tentang Petunjuk Pelaksanaan Peraturan Daerah Kabupaten Sleman Nomor 11 Tahun 2010 tentang Jaminan Kesehatan Daerah di Puskesmas Depok Sleman Tahun 2013. Kedua, kendala-kendala apa saja yang dihadapi dalam pelaksanaan jaminan kesehatan daerah di Puskesmas Depok Sleman. Ketiga, upaya untuk mengatasi kendala dalam pelaksanaan jaminan kesehatan daerah di Puskesmas Depok, Sleman.

\section{METODE PENELITIAN}

Penelitian ini bersifat penelitian yuridis empiris. Penelitian yuridis empiris adalah penelitian hukum mengenai pemberlakuan atau implementasi ketentuan hukum normatif secara in action pada setiap peristiwa hukum tertentu yang terjadi dalam masyarakat (Muhammad, 2004: 134.)

Penelitian ini dilakukan dengan penelitian lapangan yang ditujukan pada implementasi jaminan kesehatan daerah setelah berlakunya Peraturan Bupati Sleman Nomor 60 Tahun 2012 Tentang Petunjuk Pelaksanaan Peraturan Daerah Kabupaten Sleman Nomor 11 Tahun 2010 di Puskesmas Depok Sleman Tahun 2013. Penelitian ini dilaksanakan di Puskesmas Depok Sleman, terdiri dari Puskesmas Depok I, Depok II dan Puskesmas Depok III. Tipe penelitian 
deskriptif, yaitu memberikan gambaran secara jelas mengenai masalah-masalah yang diteliti, mengidentifikasi dan menjelaskan data yang ada secara sistematis. Tipe deskriptif didasarkan pada peristiwaperistiwa yang terjadi pada saat peneliti melakukan penelitian kemudian menganalisanya dan membandingkan dengan kenyataan yang ada dengan teori, dan selanjutnya menarik kesimpulan. Cara penelitian dilakukan dengan survey.

Sehubungan dengan rumusan masalah yang diangkat dalam penelitian ini, maka yang menjadi unit analisis adalah program kesehatan daerah yang dilaksanakan di Puskesmas Depok Sleman didasarkan pada pertimbangan bagaimana implementasi program kesehatan daerah di Kabupaten Sleman sebagai kebijakan yang ditetapkan oleh pemerintah daerah untuk memberikan kesehatan berkualitas bagi seluruh masyarakat khususnya di Puskesmas Depok Sleman

\section{HASIL DAN PEMBAHASAN}

\section{Implementasi Jaminan Kesehatan}

Daerah Setelah Berlakunya Peraturan Bupati Sleman Nomor 60 Tahun 2012

Berdasarkan pengelolaannya, peserta jaminan pembiayaan kesehatan adalah sebagai berikut.
1. Pusat/Nasional: Jaminan Kesehatan Nasional (JKN) 573.648 jiwa $(53,98 \%)$ yang termasuk di dalamnya Penerima Bantuan Iuran (PBI APBN) penduduk miskin dan rentan miskin 317.180 jiwa (29,84\%), Pekerja Penerima Upah (PPU) 22,25\%, dan pekerja bukan penerima upah $1,88 \%$.

2. Kabupaten Sleman: Peserta Jamkesda mengiur secara mandiri sebesar 21,330 jiwa (2,01\%), jaminan kesehatan yang dibiayai daerah (Penerima Bantuan Iuran Daerah) secara keseluruhan 5,95\%, yang terdiri dari Jamkesda miskin 39,464 jiwa, perangkat desa dan Leluarga 6.253 Jiwa, PP7,381 jiwa $(0,69 \%)$ dan Jamkesus difabel sebanyak 6,104 jiwa $(0,57 \%)$.

3. Koordinasi manfaat (COB) DIY Kabupaten Sleman: Penduduk rentan miskin sebanyak 68,668 jiwa $(6,46 \%)$.

4. Honor Daerah 1.020 jiwa, Kader Institusi Masyarakat Pedesaan 8.225 jiwa. Kader BKM 406 jiwa, Kader Pos Yandu 3500 jiwa dan linmas 4,415 Jiwa.

5. Swasta: asuransi swasta 81,482 jiwa $(7,67 \%)$.

Pelaksanaan program Jamkesda didasari oleh Undang-Undang Dasar 1945 
Pasal 28 huruf $\mathrm{H}$ yang menyatakan bahwa jaminan sosial adalah "Hak setiap warga Negara," kemudian di dalam oleh UndangUndang Nomor 36 tahun 2009 tentang Kesehatan juga disebutkan bahwa "Pemerintah mengembangkan, membina, dan mendorong jaminan pemeliharaan kesehatan masyarakat," selanjutnya di dalam Undang-Undang Nomor 32 Tahun 2004 tentang Pemerintahan Daerah sebagaimana diubah menjadi Undang-Undang Nomor 23 Tahun 2014 yang disebutkan bahwa "Pemerintah daerah wajib untuk mengembangkan suatu sistem jaminan kesehatan."

Badan penyelenggara Jamkesda di Kabupaten Sleman adalah Unit Pelaksana Teknis Jaminan Pemeliharaan Kesehatan Masyarakat

(UPT-JPKM). Penyelenggaraan Jaminan kesehatan di Kabupaten Sleman barawal Tahun 1979, yaitu dengan dikembangkannya Kelompok Dana Sehat melalui Pembangunan Masyarakat Desa (PKMD), periode ini berlanjut hingga pada tahun 1999 melalui Program Jaring Pengaman Sosial Bidang Kesehatan (JPSBK). Dinas Kesehatan Kabupaten Sleman bekerjasama dengan Koperasi Pegawai Repblik Indonesia (KPRI MAKMUR) menyelenggarakan sistem jaminan kesehatan Masyarakat (JPKM) terutama bagi masyarakat miskin.

Melalui studi kelayakan dibentuklah Unit Pelaksana Teknis Daerah (UPTD) JPKM dengan berdasar pada Surat Keputusan Bupati Sleman nomor 21/Kep.KDH/A/2002 tentang Pembentukan UPTD JPKM pada tanggal 17 Juni 2002. Seiring dengan adanya penataan organisasi perangkat daerah pada tanggal 15 Oktober 2009 status UPTD JPKM berubah menjadi UPT JPKM dengan keluarnya Peraturan Bupati Sleman Nomor 53 Tahun 2009 tentang Pembentukan Unit Pelaksana Teknis Jaminan Pemeliharaan Kesehatan Masyarakat.

Pada tanggal 12 November 2010 Pemerintah Kabupaten Sleman dengan persetujuan DPRD mengesahkan Peraturan Daerah Nomor 11 Tahun 2010 tentang Jaminan Kesehatan Daerah (Jamkesda). Peraturan ini menyatukan sistem jaminan kesehatan sekaligus mengubah nama program dari JPKM menjadi Jamkesda. Penyatuan sistem ini dibarengi pula dengan perbaikan sistem pengelolaan keuangan sehingga melalui Keputusan Bupati Sleman Nomor 386/Kep.KDH/A/2010 tanggal 27 Desember 2010 UPT JPKM secara resmi menerapkan Pola Pengelolaan Keuangan 
Badan Layanan Umum Daerah (PPKBLUD). Peraturan Daerah Nomor 11 Tahun 2010 tentang Jamkesda kemudian direvisi dengan Peraturan Daerah Nomor 20 tahun 2012 tentang Perubahan atas Peraturan Daerah Nomor 11 Tahun 2010 yang efektif diterapkan pada tanggal 1 Januari 2013 yang diikuti terbitnya Peraturan Bupati Sleman Nomor 60 Tahun 2012 Tentang Petunjuk Pelaksaan Peraturan Daerah Kabupaten Sleman Nomor 11 Tahun 2010 di Puskesmas Depok Sleman.

Peserta Program Jamkesda adalah setiap orang yang terdaftar dan memiliki Kartu Tanda Penduduk (KTP) Daerah Sleman dan berhak mendapatkan pelayanan kesehatan setelah terdaftar sebagai peserta Jamkesda yang dibuktikan dengan kepemilikan kartu Kepesertaan Jamkesda. Setiap peserta Jamkesda mempunyai hak mendapatkan pelayanan kesehatan dasar meliputi pelayanan kesehatan rawat jalan dan rawat inap, serta pelayanan kesehatan rujukan rawat jalan tingkat lanjutan (RJTL), rawat inap tingkat lanjutan (RITL), pertolongan persalinan dan pelayanan gawat darurat.

\section{Prosedur Pelayanan}

Prosedur untuk memperoleh pelayanan kesehatan bagi peserta, sebagai berikut:
1. Pasien yang memerlukan pelayanan kesehatan bisa langsung ke pelayanan kesehatan baik di Puskesmas/ PPK I, dokter keluarga, Bidan yang sudah kerjasama dengan UPT. JPKM.

2. Pasien harus bisa menunjukkan bukti kepesertaan Jamkesda dengan membawa kartu peserta Jamkesda.

3. Pemberi pelayanan akan mendaftar pasien dan mencatat dalam kunjungan pasien Jamkesda selanjutnya pasien melakukan tanda tangan ,untuk selanjutnya sebagai bukti pemberi pelayanan mengajukan klaim ke UPT. JPKM.

4. Apabila peserta Jamkesda memerlukan pelayanan kesehatan rujukan, maka yang bersangkutan dirujuk ke fasilitas kesehatan rujukan (Puskesmas Perawatan/ RSUD) disertai surat rujukan, KTP, KK, dan kartu peserta yang ditunjukkan sejak awal sebelum mendapatkan pelayanan kesehatan, kecuali pada kasus emergency.

Jaminan Kesehatan Daerah ini sendiri dibedakan menjadi 2 (dua) jenis yaitu Jamkesda Miskin/Rentan Miskin yaitu yang sudah ditetapkan dengan Keputusan Bupati yaitu untuk wilayah Kabupaten sebesar 458.662 jiwa dan peserta jamkesda mandiri dengan premi membayar sendiri, dalam pelaksanaannya masyarakat miskin yang 
sudah terdata oleh Pemerintah Daerah akan mendapatkan kartu Jamkeda dengan premi di bayar oleh pemerintah daerah yang dapat digunakan di Puskesmas atau rumah Sakit yang telah di tunjuk oleh Pemerintah. Jenis yang kedua adalah Jamkesda mandiri dengan manfaat yang diperoleh sama dengan peserta Jamkesda miskin.

Dari hasil wawancara kepada informan yang terkait dengan pelaksanaan program Jamkesda ini peneliti juga menemukan sejumlah kendala baik bagi peserta, pemberi pelayanan maupun pemerintah Daerah Sleman sendiri, antara lain yakni:

1. Puskesmas sangat ketat dalam memberikan pelayanan dalam arti mengikuti petunjuk teknis yang ada (Peraturan Bupati Sleman No 60 tahun2012).

2. Apabila pelayanan tidak sesuai dengan dengan juknis klaim tidak akan dibayar oleh UPT Jamkesda. Apabila pasien memaksa mendapatkan pelayanan menyimpang dari juknis, pasien diberi penjelasan terlebih dahulu, apabila ada kesepakatan menghendaki biaya sendiri maka pasien dilayani. Pada prinsipnya semua pelayanan yang diberikan harus sesuai indikasi medis sehingga pasien akan terlayani gratis tidak ada biaya tambahan.
3. Untuk pelayanan di puskesmas tidak ada masalah, tetapi di rumah sakit ternyata harus menambah biaya, karena untuk tindakan cuci darah dengan proggram jamkesda ada pembatasan maksimal $\mathrm{Rp} 500.000$,(lima ratus ribu rupiah).

4. Pelaksanaan program Jamkesda di Kabupaten Sleman perlu diapresiasi, karena sangat membantu khususnya bagi warga Sleman, tetapi dalam pelaksanaannya perlu ada pelayanan lainnya seperti Keluarga Berencana (KB) khususnya bagi keluarga miskin, karena masyarakat sangat membutuhkannya.

5. Untuk pemeriksaan kesehatan, adanya program Jamkesda sangat meringankan sekali, karena peserta dapat berobat gratis, namun yang menjadi masalah adalah meskipun peserta mendapat kartu Jamkesda miskin, tetapi untuk pelayanan suntik $\mathrm{KB}$, peserta tetap harus bayar sendiri karena tidak dijamin Jamkesda.

6. Untuk rawat inap pasien dan atau keluarga pasien harus menyelesaikan semua surat-surat yang diperlukan untuk memperoleh penjaminan Jamkesda dalam waktu 2 X 24 jam. Ketentuan waktu seperti ini seringkali menyulitkan keluarga pasien di 
Kecamatan Depok Sleman karena mereka harus berkejaran dengan waktu untuk mengurus surat-surat tersebut sebagai syarat administrasi, sementara instansi yang terkait dengan surat-surat tersebut seringkali lambat dalam mengurus surat oleh karena itu diperlukan kerja sama dan koordinasi yang baik diantara pihak-pihak terkait.

7. Adanya pihak pihak yang tidak bertanggung jawab (calo) dalam pengurusan suratsurat mendaftar sebagai peserta Jamkesda.

8. Masih ditemukannya kepesertaan Jamkesda salah sasaran, masuk dalam daftar keluarga miskin tetapi tidak mendapatkan kartu kepesertaan Jamkesda, dan sebaliknya keluarga mampu tetapi masuk dalam kepesertaan Jamkesda.

9. Penyediaan kamar kelas 3 di Rumah Sakit Besar Swasta bagi peserta Jamkesda hanya dialokasikan sebesar 5\% dari jumlah total kamar kelas 3 yang tersedia di rumah sakit tersebut. Jadi, sebelum menerima pasien Jamkesda, rumah sakit akan memeriksa ketersediaan kuota kamar kelas 3 bagi peserta Jamkesda dan apabila kuota telah terpenuhi rumah sakit akan menolak pasien tersebut. Akibatnya pasien terpaksa harus mencari rumah sakit lain. Akan menjadi sangat berisiko apabila ternyata pasien tengah dalam kondisi darurat dan membutuhkan pertolongan secepat mungkin, keluarga pasien pasti akan dengan terpaksa memasukannya ke dalam Instalasi Gawat Darurat (IGD) dan menggunakan jasa pelayanan umum. Apabila keluarga pasien menggunakan jasa tersebut, otomatis mereka harus membayar sejumlah uang tertentu dan uang tersebut tidak mendapatkan reimburse apabila klaim Jamkesda turun, yang dijamin oleh Jamkesda dalam kasus seperti ini hanya penanganan pada IGD, bukan pelayanan Jasa Umum rumah sakit.

10. Data kemiskinan merupakan data yang bersifat dinamis, perubahan data masyarakat miskin dapat terjadi setiap saat dan tidak dapat bergantung selamanya pada data badan Pusat Statistik (BPS). Oleh karena itu peran kader-kader kesehatan yang ada di setiap RW sangat penting dalam hal memperbaharui data peserta Jamkesda. Setiap perubahan seperti kematian, kelahiran, penurunan kemampuan ekonomi (penambahan angka kemiskinan yang memungkinkan penambahan calon peserta Jamkesda), 
ataupun peningkatan kemampuan ekonomi peserta (peserta Jamkesda yang dianggap bertambah kaya/ telah menjadi kaya) harus selalu dikabarkan oleh kader kepada petugas pendataan. Tujuannya adalah hasil data ini dapat dijadikan salah satu indikator kemiskinan untuk perbandingan antara data Dinas Kesehatan setempat dengan data kemiskinan BPS.

11. Tidak ada pembatasan kuota atau pembatasan jumlah peserta Jamkesda untuk setiap kelurahan yang ada di Kabupaten Sleman. Berdasarkan hasil penelitian, pemberian kuota bagi setiap kelurahan bagai pisau bermata dua, dimana pada satu sisi dengan adanya kuota akan membatasi jumlah peserta yang berhak menerima Jamkesda karena sekali lagi data kemiskinan bersifat dinamis dan tidak pasti setiap waktu, namun apabila Jamkesda ini diberlakukan tanpa kuota akan membebani APBD kabupaten Sleman.

12. Terkait dengan rawat jalan tingkat lanjutan dilakukan di rumah sakit yang berada di luar wilayah kabupaten Sleman, Jamkesda tidak dapat membantu pembiayaan sebelum Rumah sakit tersebut melakukan perjanjian kerjasama dengan UPT. JPKM. Hal ini sesuai dengan
Peraturan Bupati Nomor 60 tahun 2012 tentang Juknis Jamkesda Pasal 18 ayat (1) yang disebutkan bahwa "Penyelenggaraan pelayanan kesehatan tingkat lanjutan di rumah sakit dan klinik utama yang bekerjasama dengan UPT. JPKM, namun masih dimungkinkan apabila pasien sangat membutuhkan rujukan pada rumah sakit yang belum kerjasama dengan UPT. JPKM dikarenakan rumah sakit yang ada (Tipe A RSUP dr Sarjito) menghendaki untuk dirujuk ke Rumah Sakit Cipto Mangunkusuma (RSCM), Jamkesda membantu pembiayaan sepanjang Rumah Sakit yang dituju bersedia menerima ketentuan Jamkesda.

Klaim biaya pelayanan kesehatan diajukan PPK ke penyelenggara Jamkesda paling lama pada tanggal 6 (enam) bulan berikutnya dari bulan pelayanan yang telah dilakukan dengan menggunakan surat permohonan yang ditandatangani Kepala/Direktur PPK.

Verifikasi dilakukan untuk memastikan bahwa pelayanan kesehatan benar-benar telah diberikan oleh PPK kepada peserta Jamkesda yang dikuatkan dengan bukti-bukti administrasi dan untuk memastikan kesesuaian biaya pelayanan 
dengan tarif yang ditentukan dalam Peraturan Bupati ini;

Pelaksanaan program Jamkesda didasari oleh Undang-Undang Dasar 1945 Pasal 28 huruf $\mathrm{H}$ yang disebutkan bahwa "Jaminan sosial adalah hak setiap warga Negara.” Di dalam UUD 1945 Pasal 34 ayat (2) disebutkan bahwa "Negara mengembangkan sistem jaminan sosial bagi seluruh rakyat dan memberdayakan masyarakat yang lemah dan tidak mampu sesuai dengan martabat kemanusiaan," selanjutnya di dalam ayat (3) disebutkan bahwa "Negara bertanggung jawab atas penyediaan fasilitas pelayanan kesehatan dan fasilitas pelayanan umum yang layak."

Dalam Undang-Undang Nomor 36 tahun 2009 tentang Kesehatan Pasal 170 Ayat (3) disebutkan bahwa "Sumber pembiayaan kesehatan berasal dari pemerintah, pemerintah daerah, masyarakat, swasta dan sumber lain.”

Di dalam Undang-Undang Nomor 32 Tahun 2004 tentang Pemerintahan Daerah sebagaimana diubah menjadi UndangUndang Nomor 23 Tahun 2014 Pasal 22 yang disebutkan bahwa "Pemerintah Daerah Wajib untuk mengembangkan suatu sistem jaminan kesehatan.” Upaya ini kemudian didukung oleh pemerintah Kabupaten Sleman dengan dikeluarkannya Perda No. 11
Tahun 2010 tentang Jaminan Kesehatan Daerah sebagaimana telah diubah dengan Peraturan Daerah Kabupaten Sleman Nomor 20 Tahun 2012 tentang Perubahan Atas Peraturan Daerah Daerah Kabupaten Sleman Nomor 11 Tahun 2010 tentang Jaminan Kesehatan Daerah. Keberadaan Perda tentang Jamkesda ini sangat penting karena tanpa adanya suatu payung hukum maka pemerintah Daerah Sleman akan mengalami kesulitan dalam menyelenggarakan program ini.

Sesuai dengan UUD 1945, kesehatan adalah hak setiap orang oleh karena itu diperlukan upaya agar setiap orang dapat pelayanan kesehatan, bagi masyarakat tidak mampu sebelumnya Kementerian Kesehatan telah memberlakukan Program Askeskin dan Jamkesmas, namun program-program tersebut belum mampu mengakomodir seluruh masyarakat miskin yang ada di Daerah Sleman. Oleh karena itu, pemerintah Daerah Sleman berusaha mengcover hal tersebut dengan menyelenggarakan program Jamkesda yang dananya diperoleh dari APBD.

Peserta Program Jamkesda adalah setiap orang yang terdaftar dan memiliki Kartu Tanda Penduduk (KTP) Daerah Sleman dan berhak mendapatkan pelayanan kesehatan setelah terdaftar sebagai peserta Jamkesda yang dibuktikan dengan 
kepemilikan kartu kepesertaan Jamkesda. Dengan syarat sebagai penduduk kabupaten Sleman minimal sudah tercatat enam (6) bulan tinggal di Sleman yang dibuktikan dengan tanggal yang tercantum di Kartu Keluarga (KK). Setiap peserta Jamkesda mempunyai hak mendapatkan pelayanan kesehatan dasar meliputi pelayanan kesehatan rawat jalan dan rawat inap, serta pelayanan kesehatan rujukan rawat jalan tingkat lanjutan (RJTL), rawat inap tingkat lanjutan (RITL), pertolongan persalinan dan pelayanan gawat darurat.

1. Peserta yang memerlukan pelayanan kesehatan yang tergolong masyarakat miskin, penduduk yang memiliki KTP tetap Daerah Sleman dan belum memiliki asuransi Kesehatan lain.

2. Administrasi kepesertaan meliputi : registrasi, penerbitan dan pendistribusian kartu sampai ke peserta sepenuhnya menjadi tanggung jawab UPT JPKM dibantu Puskesmas.

3. Penduduk Daerah Sleman yang belum memiliki kartu Jamkesda tapi terdaftar dalam SK Bupati sebagai keluarga miskin atau rentan miskin, dapat mengajukan surat keterangan rentan miskin di Kantor KBBPM (Keluarga Berencana dan Badan Pemberdayaan Masyarakat) dengan hak sama dengan peserta KKM.
4. Pendaftaran peserta Jaminan Kesehatan Daerah Mandiri dilaksanakan setiap hari kerja.

5. Bagi masyarakat yang tergolong mampu namun kemudian ternyata menderita sakit yang tergolong penyakit berat berdasarkan hasil diagnosis dokter, dapat mengajukan permohonan sebagai peserta JAMKESDA mandiri.

6. Bagi anggota PNS yang memiliki anggota keluarga yang tidak tertanggung (tidak memiliki jaminan kesehatan) berhak untuk ikut program Jaminan Kesehatan Daerah.

7. Peserta penerima bantuan iuran/ PBI Jamkesda oleh Pemerintah Daerah sebagaimana dimaksud dalam Pasal 5 meliputi:

a. peserta Jamkesda dari penduduk miskin Kabupaten Sleman;

b. peserta Jamkesda dari penduduk rentan miskin Kabupaten Sleman;

c. peserta yang karena peran dan tugasnya sehingga yang bersangkutan beserta keluarganya mendapatkan penghargaan dalam bentuk jaminan kesehatan dari Pemerintah Daerah; dan

d. peserta penyandang cacat penduduk Kabupaten Sleman.

Iuran kepesertaan Jaminan Kesehatan Daerah terdiri dari: 
a. Peserta Jamkesda PBI (SK Bupati) Iuran di ayar oleh pemerintah daerah dengan besaran Rp 26.250,- (dua puluh enam ribu dua ratus lima puluh rupiah) perbulan.

b. Peserta Jamkesda Mandiri Iuran Rp 10.000,- (sepuluh ribu rupiah) per jiwa perbulan dibayarkan sekali dalam setahun besaran $\mathrm{Rp}$ 120.000,- (seratus dua puluh ribu rupiah), Rp 16.250,- (enam belas dua ratus lima puluh rupiah) per jiwa per bulan disubsidi pemerintah daerah.

Pembuatan kartu peserta Jamkesda sebesar Rp 1.000,- (seribu rupiah) per kartu per jiwa per tahun. Iuran tersebut dibayarkan sekaligus untuk 1 (satu) tahun masa kepesertaan Jamkesda. Iuran peserta Jamkesda dan biaya pembuatan kartu dibayarkan pada saat pendaftaran peserta Jamkesda. Iuran peserta Jamkesda dan biaya pembuatan kartu dibayarkan ke penyelengara jamkesda.

Terkait dengan pembiayaan ini, Pemerintah Daerah menerapkan ketentuan sebagai berikut:

1. Pemerintah Daerah mengikutsertakan peserta Jamkesda dengan iuran dibayar pemerintah ke dalam paket pelayanan kesehatan tambahan.
2. Peserta Jamkesda Mandiri yang berasal dari penduduk Kabupaten Sleman diikutkan dalam kepesertaan Jamkesda dengan paket pelayanan kesehatan tambahan, dengan selisih iuran disubsidi dari pemerintah sesuai kemampuan keuangan daerah.

3. Peserta Jamkesda mandiri yang berasal dari luar penduduk Kabupaten Sleman dilayani sesuai dengan paket pelayanan yang diikuti.

4. Peserta Jamkesda Mandiri, apabila menggunakan paket pelayanan dibiayai tidak berdasar paket INACBG's, tetapi menggunakan pola pembayaran sebagaimana dimaksud dalam Perbup Sleman Nomor 60 Tahun 2012 sebagaimana diubah dalam Pasal 18 ayat (4) Peraturan Bupati Sleman Nomor 54 Tahun 2013.

5. Selisih pembiayaan antar pelayanan kesehatan bagi peserta Jamkesda Mandiri ditanggung oleh peserta Jamkesda secara iuran biaya.

Sumber pembiayaan untuk pelaksanaan Program Jaminan Kesehatan Daerah tahun 2013 dialokasikan dari APBD daerah Sleman. Sistem Jaminan Kesehatan Daerah menggunakan pendekatan Jaminan Pemeliharaan Kesehatan Masyarakat oleh karenanya dalam alokasi pembiayaan 
menggunakan perhitungan premi yang ditetapkan setiap tahunnya dan dibayar dimuka (pra upaya) sebelum pelayanan kesehatan diberikan. Besaran Premi tahun 2013 adalah Rp 10.000,- (Sepuluh Ribu Rupiah) untuk 1 (satu) jiwa per bulan sehingga alokasi dana keseluruhan untuk 194.847 peserta sehingga berjumlah total $\mathrm{Rp}$ 23.381.640.000,-.

Peraturan Bupati (Perbup) Sleman Nomor 60 Tahun 2012 merupakan salah satu bentuk implementasi dengan pendekatan top down, yang mana kebijakan tersebut tersentralisasi dari aktor pada tingkat pusat dalam hal ini Pemerintah Daerah D.I. Yogyakarta kepada Pemerintah Kabupaten Sleman, selanjutnya diteruskan oleh administrator dan birokrat-birokrat di level bawahnya yaitu Dinas Kesehatan Kabupaten Sleman.

Beberapa hal yang mendukung dan menghambat kebijakan Peraturan Bupati Sleman Nomor 60 Tahun 2012, Berdasarkan hasil penelitian maka beberapa hal ini menjadi faktor-faktor yang mempengaruhi implementasi program Jamkesda, sehingga dapat dipaparkan sebagai berikut:

1. Komunikasi

Kabupaten Sleman terdapat sedikit inkonsistensi karena pada persyaratan administrasi tertentu sering berubah-ubah dan terjadi penambahan persyaratan yang ada di luar Perbup No. 60 Tahun 2012, hal ini dilakukan untuk meningkatkan selektivitas penerima Kartu Keluarga Miskin (KKM). Namun demikian pelaksanaan komunikasi kepada masyarakat melalui media visual maupun audiovisual telah tersalurkan dengan dengan baik, dan menurut masyarakat sendiri telah cukup jelas dan dipahami. Di mana masyarakat membutuhkan penjelasan mengenai ketentuan program Jamkesda, di tempat itu pula mereka telah mendapatkan informasi yang dibutuhkan.

2. Sumber Daya

Sumber Daya yang dimaksud ialah meliputi ketersediaan staf (tenaga kerja) dan fasilitas fisik (fasilitas kesehatan) yang dapat mendukung proses implementasi kebijakan. Dari hasil pengamatan yang telah diperoleh, sumber daya manusia (staf) yang digunakan Dinas Kesehatan (Dinkes) Kabupaten Sleman hanyalah pegawai pada bidang Pengembangan Sumber Daya Kesehatan (PSDK) dan dibantu oleh tenaga honorer (tidak tetap) yang dikontrak tahunan. Meskipun masih ada di batas kapasitas kemampuan sumber daya yang ada, namun ketika diamati di lapangan, masih diperlukan lagi beberapa personil atau mengangkat tetap tenaga honorer tersebut demi memperlancar verifikasi klaim yang sering tertunda dan 
juga memperlancar pelayanan kesehatan terhadap masyarakat peserta Jamkesda.

Untuk Fasilitas Fisik Kesehatan, sesuai dengan data yang diperoleh Kabupaten Sleman mempunyai 25 (dua puluh lima) UPT Puskesmas dan 5 (lima) di antaranya puskesmas rawat inap 1 (satu) UPT laboratorium air 1 (satu) UPT JPKM dan 2 (dua) RSUD. Beberapa fasilitas kesehatan didalamnya belum cukup memadai dan masih membutuhkan pembaruan atau penambahan perlengkapan medis. Keterbatasan tersebut mengakibatkan ketergantungan Pemkab Sleman kepada Rumah Sakit lain seperti Rumah Sakit milik Swasta . Dengan banyaknya rujukan pasien Jamkesda menuju RS milik Pemerintah maupun swasta, menyebabkan banyaknya penumpukkan klaim biaya RS yang terlambat terbayar oleh UPT. JPKM .

\section{Disposisi}

Disposisi merupakan kecenderungan sikap yang dimiliki oleh agen pelaksana kebijakan yang dapat mempengaruhi tingkat keberhasilan kinerja implementasi kebijakan, sehingga aktor pelaksana kebijakan tersebut harus memahami apa yang harus dilakukan dan diangkat berdasarkan kemampuan yang dimilikinya.

\section{Upaya Untuk Mengatasi Kendala Dalam Pelaksanaan Jaminan Kesehatan Daerah Di Puskesmas Depok Sleman}

1. Memaksimalkan Anggaran daerah untuk Pembiayaan Jamkesda

Dalam menerbitkan Kartu jamkesda miskin dan rentan miskin sekarang Berdasarkan hasil pendataan keluarga miskin yang kemudian dengan surat Keputusan Bupati Nomor: 135/Kep.KDH/A/2013 tertanggal april 2013 di terbitkan kepesertaan Jamkesda miskin72.011 dan rentan miskin 64.138 jiwa

2. Fasilitas dan Sumber Daya Kesehatan Untuk mengatasi kendala dalam pelaksanaan Jamkesda di Kabupaten Sleman maka pengadaan fasilitas dan sumber daya kesehatan ditingkatkan.

3. Adanya Pendataan (Basis Data yang Baku)

Adanya pendataan (basis data yang baku dan akurat) diharapkan persoalan data jumlah maupun identitas masyarakat yang masuk dalam kategori miskin di kabupaten Sleman dapat tercatat dengan akurat ,sehingga dapat di jadikan sebagai dasar untuk mencatat dalam daftar penerima KKM (tambahan informasi/untuk diketahui bahwa KKM selain digunakan untuk mendapatkan pelayanan kesehatan gratis juga sekaligus 
dapat digunakan untuk mendapatkan pelayanan bantuan pendidikan bagi anak sekolah mulai SD sampai dengan SMA).

4. Mengubah budaya masyarakat yang bersifat Sosio Kultural

Dengan adanya perubahan masyarakat yang bersifat Sosio Kultural maka dalam pengisian KKM harus benar-benar sesuai dengan keadaan peserta.

\section{Peningkatan kualitas SDM}

Peningkatan kualitas SDM dari seluruh personil yang ada pada UPT. JPKM Kabupaten Sleman (1 orang Kepala dan 9 orang staf) harus memiliki kapasitas menguasai bidang jaminan kesehatan dengan mengadakan pelatihan sehingga dalam merumuskan kebijakan sampai dengan melakukan evaluasi dan penyusuan laporan atas implementasi program dapat dengan mudah mendiskripsikan dengan bahasa atau konsep-konsep atau ungkapan peristilahan yang berhubungan hal-hal bersifat teknis penjaminan dan istilahistilah pada verifikasi klaim.

Guna meningkatkan kualitas pelayanan kesehatan khususnya bagi pasien peserta Jamkesda, segala kendala harus teratasi. Hal ini dilakukan sebagai salah satu bentuk upaya perwujudan pelayanan prima. Terlebih bagi peserta Jamkesda yang menderita jenis penyakit yang perlu segera perlu penangangan khusus dari tenaga kesehatan setempat.

Beberapa langkah yang dapat dilakukan adalah dengan cara sebagai berikut:

\section{Sosialisasi}

Sosialisasi dapat diberikan kepada pihak penyedia pelayanan kesehatan, seperti Rumah Sakit, Puskesmas, Klinik, atau Praktik Tenaga Kesehatan khususnya yang bekerja sama dengan Jamkesda agar dapat memberikan pelayanan kesehatan kepada pasien sesuai peraturan yang berlaku. Selain itu bagi pasien atau peserta juga diberikan sosialisasi agar mengetahui bagaimana menggunakan kartu Jamkesda serta mengetahui bagaimana melangkah saat berada dalam kondisi perlu penanganan kesehatan segera.

Sosialisasi kepada pasien dapat diberikan oleh Petugas Jamkesda maupun oleh tenaga kesehatan di tempat penyedia layanan kesehatan sesuai dengan keadaan atau kondisi

2. Penyediaan Sarana Pelayanan Kesehatan serta tenaga Kesehatan yang memadai

Hal ini tidak dapat dipungkiri bahwa kesehatan mempunyai peranan penting bagi manusia, khususnya dalam melaksanakan segala aktivitas, namun manusia terkadang dihadapkan pada suatu kondisi dimana berada dalam kondisi sakit yang tidak pernah 
diduga sebelumnya dan perlu pertolongan medis segera.

Terkait dalam penerapan Jamkesda tentu harus dapat menerapkan prinsip anti deskriminasi, maksudnya bahwa peserta Jamkesda harus mendapatkan perlakuan yang baik sesuai dengan SOP yang berlaku, tanpa membedakan dengan pasien yang berobat dengan biaya mandiri.

Hal ini juga sesuai dengan Peraturan Presiden Nomor 12 tahun 2013 tentang Jaminan Kesehatan pada Pasal 6 ayat (1), Kepesertaan jaminan kesehatan bersifat wajib dan dilakukan secara bertahap sehingga mencakup seluruh penduduk, dan ayat (2) butir b tahap kedua meliputi seluruh penduduk yang belum masuk sebagai peserta BPJS kesehatan paling lambat 1 Januari 2019, tergantung kesiapan masing-masing daerah, dimana untuk peningkatan kepesertaan JKN salah satunya adalah dengan pengembangan kepesertaan intregrasi Jamkesda ke JKN yang di mulai tahun 2015, namun dikarenakan pelaksanaan BPJS kesehatan masih ada kekurangannya dalam memberikan pelayanan kepada masyarakat, Jamkesda Sleman memanfaatkan peluang itu untuk mengelola sendiri. Oleh karenanya dalam waktu transisi tersebut, masyarakat yang masih tercover oleh Jamkesda tetap harus mendapatkan pelayanan kesehatan yang prima sesuai dengan kondisi yang dideritanya.

3. Training dan pelatihan bagi Tenaga Kesehatan

Langkah ini berkaitan erat dengan sosialisi sebagaimana disebut dalam angka 1 di atas, yang mana dalam training ini tenaga kesehatan perlu diberikan khususnya yang berkaitan dengan asuransi di bidang kesehatan,teknik verifikasi klaim termasuk tata kelola administrasi yang baik dan benar. Hal ini yang sudah dilakukan oleh Pemerintah Kabupaten Sleman selama ini agar tenaga kesehatan sebagai salah satu pelaku dalam Pelayanan Kesehatan dapat memberikan pelayanan kesehatan yang prima, tidak terkecuali bagi peserta Jamkesda.

\section{SIMPULAN}

Program Jaminan Kesehatan Daerah di Daerah Sleman ini memiliki tujuan untuk memberikan pelayanan yang bermutu dan terjangkau kepada masyarakat, memaksimalkan pembiayaan kesehatan bagi masyarakat miskin Daerah Sleman. Peserta Program Jamkesda adalah setiap orang yang terdaftar dan memiliki Kartu Tanda Penduduk (KTP) Daerah Sleman, minimal 6 bulan tinggal di Sleman di Buktikan dengan tanggal tercatat di kartu dalam kartu keluarga. Setiap peserta Jamkesda 
mempunyai hak mendapatkan pelayanan kesehatan dasar meliputi pelayanan kesehatan rawat jalan dan rawat inap, serta pelayanan kesehatan rujukan Rawat Jalan Tingkat Lanjutan (RJTL), Rawat Inap Tingkat Lanjutan (RITL), pertolongan persalinan dan pelayanan gawat darurat. Implementasi tersebut perlu disosialisasikan kepada masyarakat agar masyarakat paham dan mengetahui tentang Program Jaminan Kesehatan Daerah di Daerah Sleman.

Kendala yang dihadapi antara lain keterbatasan anggaran daerah untuk pembiayaan daerah dan fasilitas dan sumber daya kesehatan yang belum memadai. Selain itu kendala lain yang berkaitan dengan prosedural administratif, kendala yang bersumber dari pendataan, kendala yang bersifat sosio kultural serta kendala Sumber Daya Manusia (SDM) sehingga diperlukan perbaikan data base peserta jamkesda dan mengangkat pegawai/staf yang berlatar belakang pendidikan yang menguasai bidang perasuransian.

Upaya untuk mengatasi kendala dalam pelaksanaan jaminan kesehatan daerah di Puskesmas Depok Sleman yaitu: sosialisasi, penyediaan sarana pelayanan kesehatan serta tenaga kesehatan yang memadai, training dan pelatihan bagi tenaga kesehatan.

\section{DAFTAR PUSTAKA}

Barata, Atep Adya. 2003 Dasar-dasar Pelayanan Prima. Gramedia: Jakarta.

Azwar. 2006. Administrasi Kesehatan. PT.Bina Putra: Jakarta.

Winarno, Budi. 2007. Teori dan Proses Kebijakan Publik. Media Presindo: Yogyakarta.

Osborne, David dan Plastrik, Peter.1996. Banishing Bureaucracy: The Five Strategies for Reinventing Government. Addison-Wesley Publishing Company: Massachusetts.

Putra, Fadilah. 2001. Paradigma Kritis Dalam Studi Kebijakan Publik, Perubahan dan Inovasi Kebijakan Publik dan Ruang Partisipasi masyarakat dalam Proses Kebijakan Publik. Pustaka Pelajar: Surabaya.

Moenir, H. A. S. 2006. Manajemen Pelayanan Umum di Indonesia. PT. Bumi aksara: Jakarta.

Pasolong, Harbani. 2010. Teori Administrasi Publik. Alfabeta: Bandung.

Nurcholis, Hanif. 2005. Teori dan Praktik Pemerintahan dan Otonomi Daerah. PT. Grasindo: Jakarta.

Nawawi, Ismail. 2009. Public Policy Analisis, Strategi Advokasi Teori Dan Praktek. Putra Media Nusantara: Surabaya.

Kiser, Larry L dan Percy, Stephen L. 1980. The Concept of Coproduction and Its Implication for Public Service Delivery. Paper presented at the 1980 Annual Meetings of the American Society 
for Public Administration, on April 13-16. Indiana University. Bloomington.

Agustino, Leo. 2006. Dasar-dasar Kebijakan Publik. Alfabeta: Bandung.

Islamy, M Irfan. 2001. Seri Policy Analysis. Malang: Program Pasca Sarjana Universitas Brawijaya Malang.

Marschall, Melissa J. 2004. Citizen Participation and the Neighborhood Context: A New Look at the Coproduction of Local Public Goods. Political Research Quarterly. Academic Research Library.

Djumhana, Muhamad. 1994. Hukum Ekonomi Sosial Indonesia, Citra Aditya Bakti: Bandung.

Dunn, N William. 2000. Pengantar Analisis Kebijakan Publik, edisi kedua. Penerbit Gajah Mada University Press: Yogyakarta.

Effendy, Nasrul. 1998. Dasar-dasar kesehatan masyarakat. Penerbit Buku Kedokteran EGC: Jakarta.

Ratminto dan Septi, Winarsih. 2005, Manajemen Pelayanan. Penerbit Pustaka Pelajar: Yogyakarta.

Wahab, Solichin Abdul. 2005. Analisis Kebijaksanaan: dari Formulasi Ke Implementasi Kebijakan Negara. Bumi Aksara: Jakarta.

Sulastomo. 2007. Sistem Jaminan Sosial Nasional Sebuah Introduksi. Rajawali Pers. Jakarta.

Asyhadie, Zaeni. 2007. Aspek-Aspek Hukum Jaminan Sosial Tenaga Kerja di Indonesia. Rajawali Pers. Mataram.

\section{Peraturan-Peraturan}

Undang- undang Dasar 1945

Undang- undang Kesehatan nomor 36 Tahun 2009

Undang- undang nomor 40 tahun 2004 Tentang Sistim Jaminan Sosial Nasional

Peraturan Presiden Nomor 111 Tahun 2013 tentang Metode pembayaran atau iuran peserta Jaminan Kesehatan Nasional $(\mathrm{JKN})$

Peraturan Daerah Kabupaten Sleman Nomor 11 tahun 2010 tentang Jaminan Kesehatan Daerah,

Peraturan Bupati Nomor 60 Tahun 2012 tentang petunjuk Pelaksanaan peraturan Daerah Kabupaten Sleman Nomor 11 Tahun 2010. 